\title{
The Ultimate Oxymoron
}

\author{
Mary Sternberg \\ Escondido, California
}

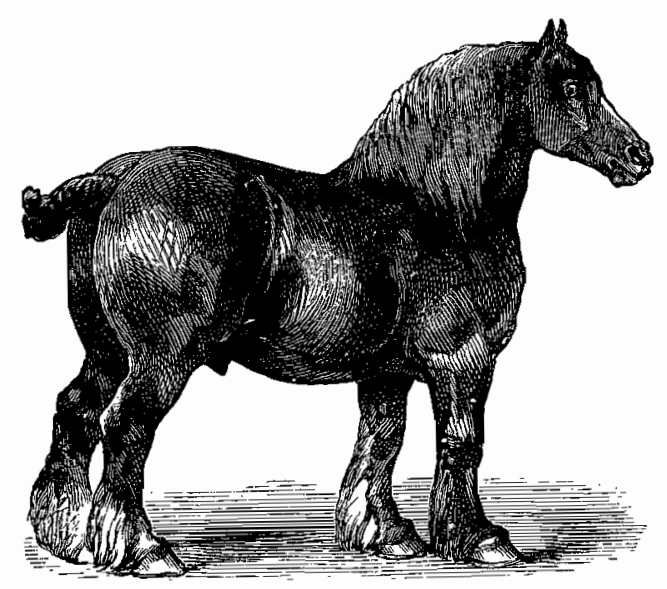

Sometimes I realize that I'm a rotten Christian. I can't, for example, no matter how much my church tries to drum it into me, believe in a cruel, insensitive, manipulative God.

I don't mean that my church always tells me that God is like that. Often, the Christian God is one I can believe in happily, for $\mathrm{He}$ is the loving, forgiving Creator of a beautifully planned universe, whereby all of His creations are interdependent and, if left to operate as He arranged it, work in a most harmonious system of checks, balances and synchronized glory.

Part of the time, however, I am taught to accept quite a different kind of God. This is a God who made a beautiful planet teeming with millions of varieties of creatures that are so magnificent in color, shape and individual abilities that no one possibly could have conceived of them except an all-powerful, allknowing Creator.

Having designed all of these splendid creatures, $\mathrm{He}$ then, in a high-handed, Machiavellian manner, decided that some of the creatures would have an eternal heavenly existence, while others would be destined to one brief, thoroughly miserable life on earth and then have their unhappy breaths forever extinguished.

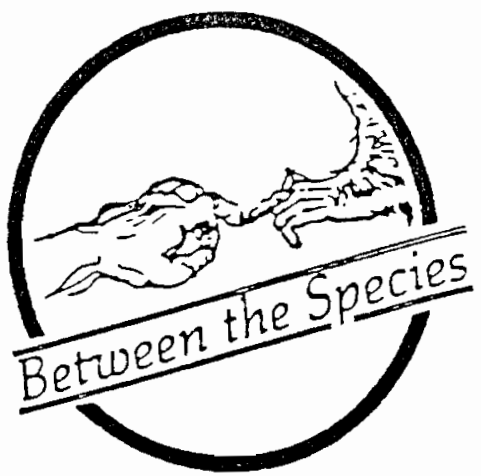

Curiously, the Creator did not select those who were to live forever because they had led good, unselfish or exceptionally noble lives during their earthly habitation, while those who were chosen to be permanently snuffed out had been cruel and evil. Quite the contrary. Those chosen for an eternal, heavenly existence might have been utter louts who rarely had committed a decent act in their entire lives. Yet, so long as they accepted their Lord and Maker and asked His forgiveness, even if it were not until their dying breaths, they were destined for eternal life.

The others, innocent creatures who had harmed no one, and who, through no fault of their own, were cruelly mistreated throughout their lives, were given no chance at any future life. They were to have just one brief life of suffering and that was that.

This is the kind of Christian God I am asked to believe in. I just can't do it. The whole thing would lead one to question the very desirability of the concept of eternal life. It seems to turn some of the basic tenets of Christianity topsy-turvy.

Specifically, who are these creatures who receive such diverse and unequal treatment at the hands of their Creator?

Let's look first at those beings, called human, who were designed by Him and given a sense of right and wrong and yet who, about eight times out of ten, choose the wrong. Their religion teaches them to love their

(C) Copyright M. Sternberg, 1993

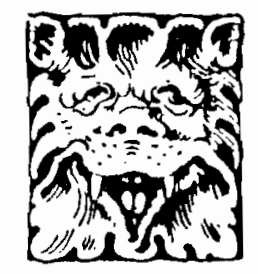


neighbors, yet their world is filled with jealousy, hatred, ethnic discrimination, turmoil and wars. They are taught to help the poor and under-privileged, yet their earth overflows with those who starve with no way to escape their deprivation. They are taught to eschew money and material things, yet they worship these above everything else. They will lie for them, steal for them, even kill for them.

The list of contradictions between the spiritual and practical lives of these human creatures could go on for pages. It all boils down to the fact that, hy and large, they give lip service to what their religion teaches them while acting in ways quite contrary to these beliefs.

These are the beings that God has chosen for eternal life. They are to be rewarded handsomely for living lives that have exiguous relationship to their religion.

They believe that they are granted this afterlife boon because they are the Creator's favorites. After all, they are made in His image, or so their Bible tells them; they are given free will and are told "not to worry, that nobody's perfect." Highlighting all these special favors, they believe that the Creator endowed them with something that He gave to no other of His creatures. He gave them a ready-made, built-in, self-operating soul. This is the superior quality they possess that gets them to Heaven, while all of God's other creatures, who they say lack these souls, must be doomed to one comparatively short life.

These short-lived creatures, called animals, were fashioned by the Creator long before He ever conceived of those called human. He filled the seas with thousands of varieties and species of them. He covered the continents, both on land and in the air, with millions more. Each was wonderful in design, living in a system that was interdependent and stable in its diversity.

Not only were these creatures marvelous in their ability to live harmoniously in the roles the Creator had assigned them, they were also possessed of particularly delightful natures. They had most of the good qualities of the long-lived human creatures and few of the bad ones. They were loving, loyal, obedient, patient and uncomplaining. They were free of guile, deception, meanness, cruelty and jealousy. They were innocent, trusting creatures who wanted only to live their normal, natural lives. When God created them, he had pronounced them "good."

Had they been permitted to lead normal lives, their short time on earth would have been good. Rarely was such a thing ever granted to any of them. Instead, no matter what their kind or species, whether they flew the skies, swam the seas or trod the earth, all were cruelly exploited by the human creatures.

If they were beautiful, human beings caught them in painful traps and killed them in order to wear their skins on their own backs. If they were gentle and trusting, human beings made pets out of them which they often discarded when they became tired of them. Millions of these unwanted pets either starved to death, were killed on the highways, or were destroyed in the animal pounds each year.

Some animals were kept behind iron bars for human beings to stare at; some were forced to perform unnatural acts in land and water arenas for human entertainment. Others were taken from their kind as babies and raised in cramped, stressful conditions until they were slaughtered for human food. The living bodies of still others were subjected to excruciating agony in the experiments that humans conducted behind locked doors in their research laboratories.

It is these nonhuman creatures, who, during their brief lifetimes, have been subjected to every cruelty and outrage, that my religion tells me will have no future lives. One short time of misery on this earth and their lives are ended forever.

If I were to accept this, I would have to believe in a cruel God. No benevolent Deity would create innocent creatures for the single purpose of giving them a lifetime of suffering at the hands of a human species. Only Satan himself could conceive of such a thing.

And this is the quandary I find myself in. If I accept my religion's teaching about the afterlives of sentient creatures, then I also have to accept a cruel God. If I refuse to accept a cruel God, then I must question my religion's teaching on the subject of the afterlives of God's creatures. This I do most vehemently. No matter what my church says, I refuse to believe in that ultimate oxymoron-an evil God.

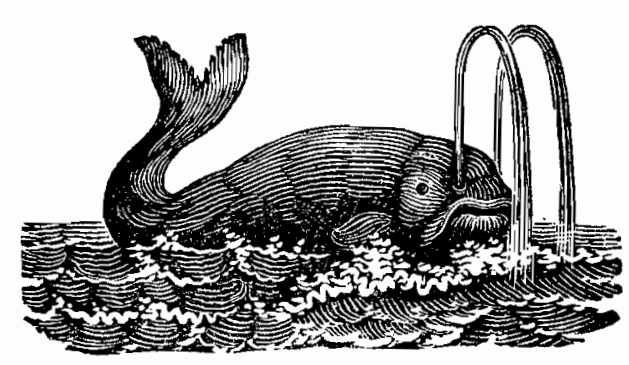




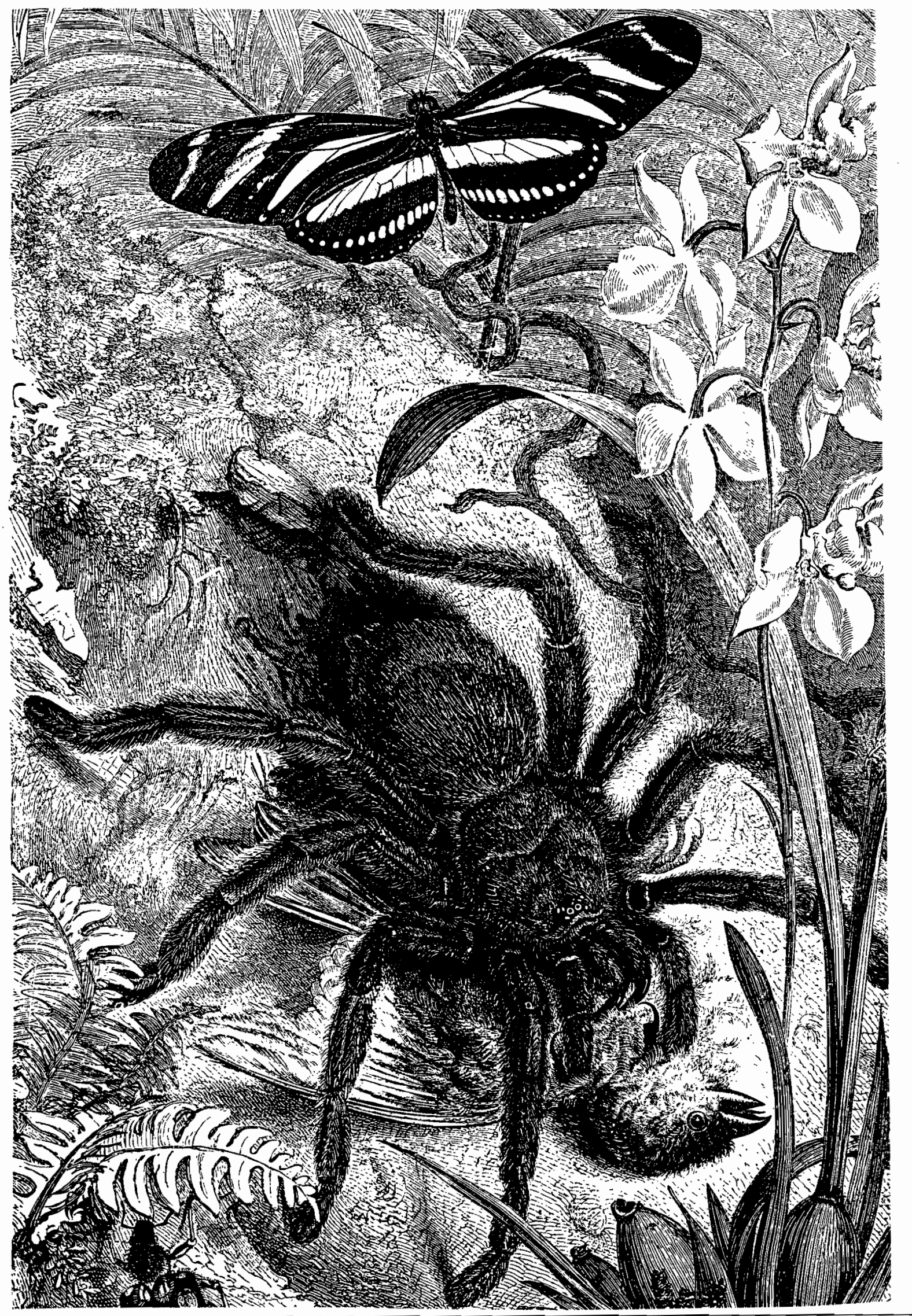

Between the Species

138

Summer \& Fall 1994 